Research Article

\title{
ORGANIC VERSUS CONVENTIONAL - A COMPARATIVE STUDY ON QUALITY AND NUTRITIVE VALUE OF SELECTED VEGETABLE CROPS OF SOUTHERN INDIA
}

\author{
J.R. Xavier", V. Mythri, R. Nagaraj, V.C.P. Ramakrishna \\ P.E. Patki and A.D. Semwal \\ Defence Food Research Laboratory, Defence Research and Development Organization, \\ Siddharthanagar, Mysore- 570 011, India
}

\begin{abstract}
Vegetables are defined as edible plant parts generally consumed raw or cooked with a main dish, in a mixed dish, as an appetizer or as a salad. Food safety aspects related to microbial quality (total plate count, yeast and mold and food borne pathogens) and toxic residue (heavy metals) and mineral content were investigated for vegetables such as green leafy vegetable, salad vegetables, sprouts, brinjal, green chilies and French beans collected from organic and conventional outlets from Mysore region, Karnataka, India. Microbial analysis was carried out using standard procedures and mminerals ( $\mathrm{Ca}, \mathrm{K}, \mathrm{Fe}, \mathrm{Cu}, \mathrm{Mg}, \mathrm{Mn}$ and $\mathrm{Zn}$ ) and heavy metals $(\mathrm{Cd}$ and $\mathrm{Pb}$ ) were determined. Significant variations ( $p>0.05)$ were observed for microbial quality among organic and conventional vegetables. Mineral and vitamin $\mathrm{C}$ content were also significantly higher $(p>0.01)$ in organic samples. Heavy metal contamination for lead and cadmium tested positive for conventional samples while organic samples tested negative. The variables that contributed most for the variability were heavy metal contamination, mineral and vitamin $\mathrm{C}$ content. Organically grown vegetables were free from heavy metals and safe for consumption, as well as they are rich in mineral and vitamin $\mathrm{C}$ content in comparison to conventional samples.
\end{abstract}

Keywords: Conventional vegetables, Microbial safety, Nutrition, Organic vegetables, Toxic residues.

\section{INTRODUCTION}

Vegetables are fresh and edible portion of herbaceous plants and form integral part of a balanced diet, utilized to build up and repair the body. Being a rich source of vitamins, minerals and dietary fiber vegetables also contain valuable food ingredients

* Corresponding author: janifer@dfrl.drdo.in 
(Eni et al., 2010). Antioxidant in vegetables is some of the important nutrients besides other vitamins, minerals, flavonoids and photochemical, which have been reported to contribute to health. Their consumption not only prevents us from many diseases but also provides taste and variety to the diet. Vegetables play a major role in increasing appetite, improve digestion and also provide valuable roughages which help in bowel movement of intestine and neutralize acids. Mysore is located in southern boundary of Karnataka state. Vegetables grown in different types of cultivation differ in quality microbial and nutritive quality as per earlier reports. Organic farming can be defined as an ecological production system that promotes and enhances biodiversity and biological cycle in soil, crop and livestock. Organic products are considered as safe for environment and human health (Somasundram et al., 2016). Heavy metal contamination of the food items is one of the most important aspects of food quality assurance. Vegetables can absorb metals from soil as well as from deposits on the parts of the vegetables exposed to the air from polluted environments (Shahid et al., 2016). Heavy metals are not biodegradable, have long biological half-lives and accumulate in different body organs leading to unwanted side effects. Lead and cadmium are among the most abundant heavy metals and are particularly toxic which leads to disruption of numerous biological and biochemical processes in the human body.

The present study was carried out to evaluate the food safety aspects related to microbial quality (total plate count, yeast and mold and specific food borne pathogens), heavy metals ( $\mathrm{Cd}$ and $\mathrm{Pb}$ ) and mineral content $(\mathrm{Ca}, \mathrm{Na}, \mathrm{K}, \mathrm{Fe}, \mathrm{Cu}, \mathrm{Mg}$, $\mathrm{Mn}$ and $\mathrm{Zn}$ ) of organically and conventionally cultivated vegetables such as green leafy vegetable, salad vegetables, sprouts (green gram, Bengal gram and horse gram), brinjal, green chilies and French beans collected from organic and conventional outlets from Mysore region, Karnataka, India. The vegetables were grouped into five major categories such as green leafy vegetables, salad vegetables, other vegetables, sprouts and protected cultivated vegetables.

\section{MATERIALS AND METHODS}

\section{Sample collection, storage and preparation}

A total of 145 fresh samples including 12 types of vegetables and 03 sprouts namely green leafy vegetables (GLV) such as amaranthus, coriander, fenugreek leaves, mint and palak, salad vegetables such as cucumber, cabbage and tomato, green chilli, cauliflower, French beans and brinjal were collected from certified outlets selling organic and conventionally grown vegetables from city of Mysore, Karnataka $\left(12.2958^{\circ} \mathrm{N}, 76.6394^{\circ} \mathrm{E}\right)($ Table 1$)$. The samples were collected over a period of five months (January to May, 2018). The samples collected were separately packed in polythene bags, labeled with codes and brought immediately to laboratory. The organic samples were labeled with codes prefixed with letter ' $O$ ' while the conventionally samples were labeled with codes prefixed with letter ' $C$ ' followed by name and number of samples collected. 
Table 1. Conventional and organic samples collected from Mysore

\begin{tabular}{|c|c|c|c|c|}
\hline Sl. No. & Sample & Scientific name & Sample code & Method \\
\hline (A) & \multicolumn{4}{|c|}{ Green leafy vegetables (GLV) } \\
\hline \multirow[t]{2}{*}{1.} & Amaranthus & Amaranthus gangeticus & CA01 & Conventional \\
\hline & & & OA01 & Organic \\
\hline \multirow[t]{2}{*}{2.} & Coriander & Coriandrum sativum & CCR02 & Conventional \\
\hline & & & OCCR02 & Organic \\
\hline \multirow[t]{2}{*}{3.} & Fenugreek & Trigonella foenum & CFE03 & Conventional \\
\hline & leaves & & OFE03 & Organic \\
\hline \multirow[t]{2}{*}{4.} & Mint leaves & Mentha spicata & CM04 & Conventional \\
\hline & & & OM04 & Organic \\
\hline \multirow[t]{2}{*}{5.} & Palak & Spinacia oleracea & CPA05 & Conventional \\
\hline & & & OPA05 & Organic \\
\hline (B) & Salad Vegetables & & & \\
\hline \multirow[t]{2}{*}{1.} & Cabbage & Brassica oleracea & СCB07 & Conventional \\
\hline & & & OCB07 & Organic \\
\hline \multirow[t]{2}{*}{2.} & Cucumber & Cucumis sativus & $\mathrm{CCC} 08$ & Conventional \\
\hline & & & OCC08 & Organic \\
\hline \multirow[t]{2}{*}{3.} & Tomato & Lycopersicone sculentum & СТ09 & Conventional \\
\hline & & & OT09 & Organic \\
\hline (C) & Other Vegetables & & & \\
\hline \multirow[t]{2}{*}{1.} & Green chilli & Capsicum annum & CGC1O & Conventional \\
\hline & & & OGC10 & Organic \\
\hline \multirow[t]{2}{*}{2.} & French beans & Phaseolus vulgaris & CFB11 & Conventional \\
\hline & & & OFB11 & Organic \\
\hline \multirow[t]{2}{*}{3.} & Cauliflower & Brassica oleracea var. & $\mathrm{CCF} 12$ & Conventional \\
\hline & & botrytis & OCF12 & Organic \\
\hline \multirow[t]{2}{*}{4.} & Brinjal & Solanum melongena & $\mathrm{CBJ} 13$ & Conventional \\
\hline & & & OBJ13 & Organic \\
\hline (E) & Sprouts & & & \\
\hline 1. & Bengal gram & Cicer arietinum & SBG1 & Conventional \\
\hline 2. & Green gram & Vigna radiata & SHG2 & Conventional \\
\hline 3. & Horse gram & Macrotyloma uniflorum & SGG3 & Conventional \\
\hline \multicolumn{5}{|c|}{ Protected cultivation } \\
\hline & Broccoli & Brassica oleracea var. italic & PBR06 & Protected \\
\hline & Strawberry & Fragaria ananassa & PSB14 & Protected \\
\hline
\end{tabular}




\section{Microbial Analysis}

Fifty grams of each sample were placed inside a sterile plastic bag with $450 \mathrm{~mL}$ of $0.1 \%$ buffered peptone water (BPW), and gently rubbed for 1 min. Mesophilic aerobic bacteria, total coliforms and yeasts and molds were enumerated and results were expressed as colony-forming units per gram $\log (\mathrm{cfu} / \mathrm{g} \log$ ). Four tenfold serial decimal dilution were made for each sample; $1 \mathrm{~mL}$ of each step was inoculated into duplicates of suitable enumeration media. For mesophilic plate count, the plates were incubated at $37^{\circ} \mathrm{C}$ for $24 \mathrm{~h}$, and for psychophilic plate count, at $6^{\circ} \mathrm{C}$ for $5-7$ days (Sospedra et al., 2013). Coliforms were analyzed by using Violet Red Bile Agar (VRBA) media using pour plate technique and plates were incubated at $35^{\circ} \mathrm{C}$ for 24 h. Estimation of yeast and mold was performed using potato dextrose agar (PDA) containing $0.1 \%$ chloramphenicol by spread plate technique and incubated at $25^{\circ} \mathrm{C}$ for 05 days. Primary characterization of bacteria was done by visual colony characters, microscopic characterization (Gram and endospore staining), motility test, oxygen tolerance test, catalase test and secondary identification of isolates was carried out based on biochemical and carbohydrate utilization test. To isolate Salmonella spp., the rinsate was used as pre-enrichment and method was carried out according to ISO 6579:2002 (2007). Salmonella Shigella Agar and EMB Agar were used and diluted samples were inoculated into the enrichment media and incubated for 24 hours at $35^{\circ} \mathrm{C}$. To enumerate $E$. coli, $1 \mathrm{~mL}$ of diluted sample was spread-plated onto eosin methylene blue (EMB) agar and plates were incubated at $37^{\circ} \mathrm{C}$ for $24 \mathrm{~h}$. Specific pathogens such as E. coli and Salmonella spp. were expressed as presence or absence.

\section{Mineral analysis}

$250 \mathrm{~g}$ of fresh samples were shade dried for 48 to $72 \mathrm{~h}$ up to the moisture content of 10 percent and homogenized using pestle and mortar. $10 \mathrm{~g}$ of the dried sample was heated in a silica crucible until the sample was carbonized, ashed at $550^{\circ} \mathrm{C}$ using muffle furnace and weighed after cooling for constant weight (AOAC 900.02). The ash was dissolved using $3 \mathrm{~N}$ for mineral and heavy metal analysis using Atomic Absorption Spectrophotometer (Varian AA 280 FS).

\section{Chemometric data processing}

To identify the relationship between samples studied, exploratory analysis using principal component analysis (PCA) and Hierarchical cluster analysis (HCA) were performed using Stat Soft Statistic version 6.0. All reported values are the mean of three replications and were subjected to one-way and two-way analysis of variance (ANOVA) using statistical software. Duncan's multiple range test was performed to find the differences between the means at $p \leq 0.05$ significance levels (Snedecor and Cochran, 1994). Results expressed as cfu/ml and treated by the Student's t-test and Manne Whitney test, depending on variable distribution, to determine whether 
microbial quality and heavy metal contamination varied significantly $(\mathrm{p}<0.05$ or $\mathrm{p}<$ 0.01 ) between conventional and organic vegetables.

\section{RESULTS AND DISCUSSION}

\section{Microbiological quality (TPS, TC and YM counts (CFU/ml)) of organic and conventionally grown vegetables}

\section{(A) Green leafy vegetables (GLV)}

In GLV, the microbial quality in terms of TPC (cfu/ml) (average mean value) for amaranthus, fenugreek leaves and palak were not on par with each other while amaranthus and mint were on par with each other while coriander, fenugreek leaves and palak were on par with each other. The microbial quality in terms of TC (cfu/ml) (average mean value) for amaranthus and palak were not on par with each other while amaranthus and fenugreek leaves \& coriander and mint are on par with each other. The microbial qualities in terms of YM (cfu/ml) (average mean value) for all five GLV are on par with each other. Highly significant differences $(\mathrm{P}<0.05)$ were found in microbial quality in terms of TPC count among the conventional and organically grown amaranthus, coriander, fenugreek leaves and mint while highly significant differences could be observed for TC count among conventional and organically grown amaranthus, fenugreek leaves and mint.

In case of $\mathrm{YM}$ count highly significantly $(\mathrm{P}<0.05)$ difference were observed among conventional and organically grown fenugreek leaves and mint while the significant difference $(\mathrm{P}<0.01)$ was observed among conventional and organically grown amaranthus, coriander and palak (Fig. 1).

Cultivation of GLVs is a profitable business for farmers; however, these vegetables are highly perishable. Therefore, these vegetables are usually grown in peri-urban area and may irrigate the crops with untreated sewage water which contains pathogenic microorganisms. Merlini et al., (2018) studied the microbiological profile of leafy vegetables from organic and conventional farming in Brazil. Their results indicated that leafy vegetables cultivated in a conventional way could present higher count of microorganisms even after the use of chemosynthetic pesticides and fertilizers. Our results were similar to the above study and highly significant differences were found for microbial quality in terms of TPC, TC and YM among conventionally and organically grown GLV.

In the study conducted by Begum and Harikrishna (2010), the bacterial contamination of GLV sampled in different places in Bangalore, palak total bacterial count (cfu/g) varied from 0.9 to too numerous to count (TNTC) while coliforms were present in negligible number upto $16 \mathrm{cfu} / \mathrm{g}$. Coriander also showed total bacterial count in terms 
of cfu/g the count between negligible to TNTC and 296, and from negligible to TNTC and 256 for coliforms. Total bacterial count was highest in coriander followed by palak. The result of total bacterial count of vegetables is an indication of improper pre- harvest and post-harvest handling. Pre-harvest conditions can come from irrigation water, improperly composted manure used as fertilizer, fecal contamination from human and domestic animals. Organically grown GLV are sold in outlets where the handling practices are hygienic till the produce reach the consumer which could be attributed to better microbial quality in comparison with conventionally grown produce.

\section{(B) Salad vegetables}

In salad vegetables, the average log mean value for TPC and TC for cucumber and tomato are on par with each other whereas average log mean value of cabbage is different. Average mean values of YM count for all salad vegetable tested are on par with each other. Highly significant differences $(\mathrm{P}<0.05)$ were found in microbial quality in terms of TPC and TC among the conventional and organically grown tomato, while significant differences $(\mathrm{P}<0.01)$ were observed among conventional and organically grown cabbage and cucumber ((Fig. 1). In contrast to their health benefits, the consumption of fresh vegetables has also been associated with risk for consumers (Weldezgina and Muleta, 2016). Vegetables are rich in carbohydrates, anti-oxidants, minerals, vitamins and fibres (Said, 2012) and often consumed uncooked. The results explain that in conventionally grown salad vegetables the microbial contamination is higher than their counterparts. In the present study, soaking of salad vegetables in sterile water for $10 \mathrm{~min}$ has resulted in reduction of microbial load, while TC count of cucumber and cabbage were higher in organically grown samples in comparison to conventionally grown samples. Viswanathan and Kaur (2000) conducted study on raw salad vegetables obtained from street vendors of Mumbai. The average aerobic plate count for salad vegetable was in the range between $10^{5}-10^{10} \mathrm{cfu} / \mathrm{g}$, their corresponding coliform counts ranged between $10^{6}-$ $10^{9} \mathrm{cfu} / \mathrm{g}$ which is on par with the present study. 
Table 2. Test for specific pathogen in conventional, organic and protected grown vegetables

\begin{tabular}{|c|c|c|c|c|c|}
\hline Sample & Method & Salmonella sp. & Shigella sp. & Bacillus cereus & Escherichia coli \\
\hline \multicolumn{6}{|l|}{ Conventionally grown } \\
\hline 1. Amaranthus & Crushed sample & Positive & Negative & Positive & Positive \\
\hline 2. Coriander & Crushed sample & Negative & Negative & Negative & Positive \\
\hline $\begin{array}{l}\text { 3. Fenugreek } \\
\text { leaves }\end{array}$ & Crushed sample & Positive & Negative & Positive & Positive \\
\hline 4. Mint & Crushed sample & Negative & Negative & Positive & Positive \\
\hline 5. Palak & Crushed sample & Negative & Negative & Negative & Positive \\
\hline 6. Cabbage & Crushed sample & Positive & Positive & Positive & Positive \\
\hline 7. Cucumber & Crushed sample & Negative & Negative & Negative & Positive \\
\hline 8. Tomato & Crushed sample & Positive & Negative & Negative & Positive \\
\hline 9. Green chilli & Crushed sample & Positive & Negative & Positive & Positive \\
\hline 10 French bean & Crushed sample & Positive & Negative & Positive & Negative \\
\hline 11 Brinjal & Crushed sample & Negative & Negative & Negative & Positive \\
\hline 12 Cauliflower & Crushed sample & Positive & Negative & Positive & Positive \\
\hline 13 Bengal gram & Crushed sample & Negative & Positive & Positive & Positive \\
\hline 14 Green gram & Crushed sample & Negative & Positive & Positive & Positive \\
\hline 15 Horse gram & Crushed sample & Negative & Positive & Positive & Positive \\
\hline \multicolumn{6}{|l|}{ Organically grown } \\
\hline 16 Amaranthus & Crushed sample & Positive & Negative & Negative & Positive \\
\hline 17 Coriander & Crushed sample & Positive & Negative & Negative & Positive \\
\hline $\begin{array}{l}\text { 18 Fenugreek } \\
\text { leaves }\end{array}$ & Crushed sample & Positive & Negative & Negative & Positive \\
\hline 19Mint & Crushed sample & Positive & Negative & Negative & Positive \\
\hline 20 Palak & Crushed sample & Negative & Negative & Negative & Positive \\
\hline 21 Cabbage & Crushed sample & Negative & Negative & Negative & Positive \\
\hline 22 Cucumber & Crushed sample & Negative & Negative & Negative & Positive \\
\hline 23 Tomato & Crushed sample & Negative & Negative & Negative & Positive \\
\hline 24 Green chilli & Crushed sample & Positive & Negative & Negative & Positive \\
\hline 25 French bean & Crushed sample & Negative & Negative & Negative & Positive \\
\hline 26 Brinjal & Crushed sample & Negative & Negative & Negative & Positive \\
\hline 27 Cauliflower & Crushed sample & Positive & Negative & Negative & Positive \\
\hline \multicolumn{6}{|l|}{ Protected cultivation } \\
\hline 28 Broccoli & Crushed sample & Negative & Negative & Negative & Positive \\
\hline 29 Strawberry & Crushed sample & Negative & Negative & Negative & Positive \\
\hline
\end{tabular}




\section{(C) Other vegetables}

In conventional and organically grown French bean and brinjal the average log mean values of TPC, TC are on par with each other. The microbial quality in terms of TPC and TC for green chilli and cauliflower are different from the microbial quality of French bean and brinjal. YM counts of brinjal are not similar with green chilli, French bean and cauliflower but YM counts of green chilli and cauliflower are on par with each other. Significant differences $(\mathrm{P}<0.01)$ were found in microbial quality in terms of TPC, TC and YM count among the conventional and organically grown cauliflower, while significant differences $(\mathrm{P}<0.01)$ were observed among conventional and organically grown green chilli for YM count (Fig. 1).
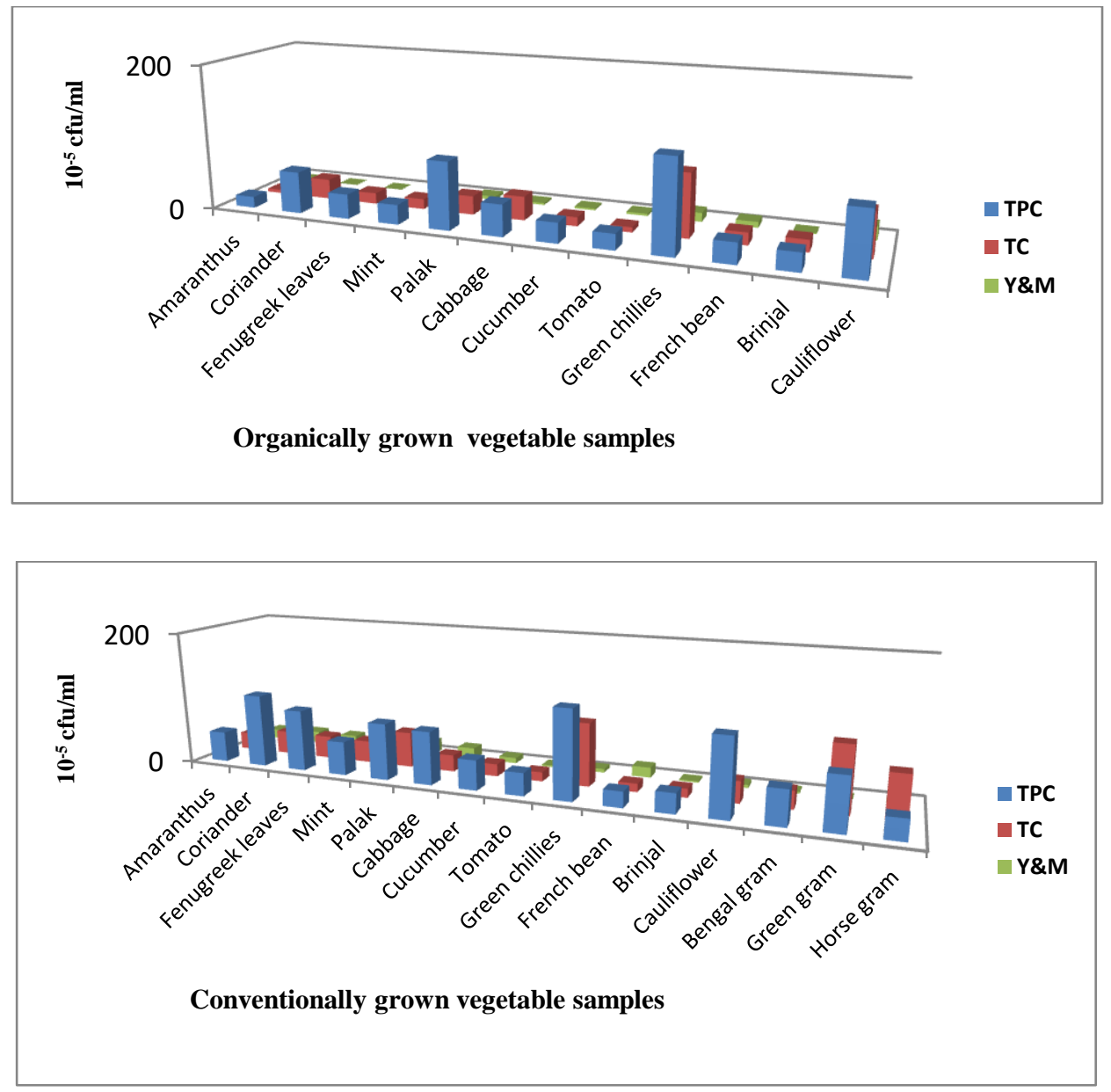

Figure 1. Microbial content in wash water sample $\left(10^{-5}\right.$ dilution) of conventionally and organically grown vegetables 
Maffei et al., (2016) briefly reviewed the current knowledge and summarized data on the occurrence of pathogenic microorganisms in organic vegetables. A number of scientific studies conducted in various countries were compared for the microbiological quality of produce from organic and conventional production and results were contradictory. A number of studies indicated that organic produce may pose a greater risk than conventional grown produce, this trend is not universal across all studies. In the present study, TPC and YM count of conventional sample has been found higher when compared with the TPC and YM of organically grown vegetables. TC values in organically grown vegetables were found to be higher in conventional samples such as cabbage, French beans, brinjal and cauliflower.

\section{(D) Conventionally grown sprouts}

In sprouts obtained from vendors, TPC ( $\mathrm{cfu} / \mathrm{ml})$ was found maximum in green gram sprouts $(77.00 \pm 22.11)$ and minimum in horse gram $(30.33 \pm 7.09)$, TC was found maximum in green gram sprouts $(97.00 \pm 5.57)$ and minimum in Bengal gram (26.33 \pm 6.43$)$ while Yeast and Mold was found maximum in Bengal gram (2.33 \pm 1.52$)$ and negligible in green gram and horse gram (Fig. 1). Seeds were soaked in water before being placed under warm and humid conditions which may be ideal for bacterial proliferation. The germination step is the main source of contamination in sprouts (US FDA, 1999). In various studies, the microbial loads in seeds were found to be between 3.0 and $6.0 \log \mathrm{CFU} / \mathrm{g}$; with sprouts having counts that were 2 or $3 \operatorname{logs}$ greater (Ren, 2009).

\section{(E) Protected cultivated crops}

Among protected cultivated crops maximum TPC (cfu/ml) was found in strawberry $(81.67 \pm 18.23)$ and minimum in broccoli $(11.00 \pm 6.24)$. TC $(\mathrm{cfu} / \mathrm{ml})$ was found maximum in strawberry $(25.3 \pm 10.21)$ and minimum in broccoli $(3.66 \pm 1.52)$. YM $(\mathrm{cfu} / \mathrm{ml})$ was found maximum in strawberry $(51.67 \pm 14.19)$ and minimum in broccoli

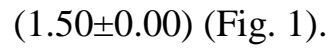

\section{Microbiological quality (specific pathogens (presence/absence)) of organic and conventionally grown vegetables}

The test for presence of specific pathogen indicated presence of E. coli among all conventionally and organically grown vegetables. Conventionally grown cabbage, tomato and French bean tested positive for Salmonella spp. contamination while organically grown samples were free of the same. Salmonella spp. contamination was noticed in organically grown coriander, mint while conventionally grown coriander and mint were found devoid of the same. Conventionally grown cabbage tested positive for Shigella sp. while all other samples tested negative for the same. $B$. cereus contamination was prevalent in conventionally grown vegetables such as amaranthus, fenugreek leaves, mint, cabbage, green chilli, French beans and cauliflower while organically grown vegetables tested negative. Cucumber, coriander, 
palak, tomato, brinjal also tested negative for B. cereus for both conventional and organic cultivation (Table 2). Severe outbreaks were traced to consumption of contaminated radish sprouts and pre-packaged spinach. Similarly, infections with Salmonella sp. were linked to consumption of foods of animal origin, many outbreaks were traced to contaminated fresh produce (Berger et al., 2010).

\section{Estimation of minerals in conventional and organically grown vegetables}

\section{(A) Green leafy vegetables (GLV)}

Minerals are naturally occurring inorganic substance present in plants. In plants, vegetables are excellent source of minerals which helps to meet RDA essential nutrients. Minerals in the crops are beside vitamins, antioxidants, flavonoids and photochemical one of the most important nutrients, which have been reported to contribute to the human health (Rembialkowska, 2007; Crinnion, 2010). Highly significant differences $(\mathrm{P}<0.05)$ were found in mineral contents of $\mathrm{Mg}, \mathrm{K}, \mathrm{Cu}, \mathrm{Zn}$, $\mathrm{Mn}$ and Vitamin $\mathrm{C}$ was observed among the conventional and organically grown GLV such as amaranthus, coriander, fenugreek leaves and mint, for $\mathrm{Fe}$ and $\mathrm{Ca}$ contents of amaranthus and fenugreek while significant differences $(\mathrm{P}<0.01)$ were observed among conventional and organically grown fenugreek and mint for $\mathrm{Ca}, \mathrm{Zn}$ and vitamin $\mathrm{C}$ contents. No significant differences were observed for all tested element for palak among conventional and organic cultivation (Table 3 and 4).

\section{(B) Salad vegetables}

Highly significant differences $(\mathrm{P}<0.05)$ were found in $\mathrm{K}$ content among all tested conventional and organically grown salad vegetables while mineral contents such as $\mathrm{Mn} \mathrm{Na} \mathrm{K} \mathrm{Mg} \mathrm{Zn} \mathrm{and} \mathrm{Vitamin} \mathrm{C} \mathrm{was} \mathrm{highly} \mathrm{significant} \mathrm{in} \mathrm{cucumber} \mathrm{and} \mathrm{Fe}, \mathrm{K}$ and Vitamin $\mathrm{C}$ content for tomato. Significant differences $(\mathrm{P}<0.01)$ were observed among conventional and organically grown cabbage for $\mathrm{Ca}, \mathrm{Fe}, \mathrm{Mg}, \mathrm{Zn}$ and Vitamin $\mathrm{C}$, tomato for $\mathrm{Ca}, \mathrm{Cu}$ and $\mathrm{Mn}$ while for only $\mathrm{Cu}$ content in cucumber (Table 3 and 4).

\section{(C) Other vegetables and sprouts}

Highly significant differences $(\mathrm{P}<0.05)$ were found in mineral contents of $\mathrm{Ca}, \mathrm{Mn}$ and $\mathrm{Zn}$ was observed among the conventional and organically grown Green chilli, for minerals $\mathrm{K}, \mathrm{Mg}$ and Vitamin $\mathrm{C}$ for brinjal, $\mathrm{Ca}, \mathrm{K}$ and $\mathrm{Zn}$ for cauliflower and only for $\mathrm{K}$ in French bean. Only significant differences $(\mathrm{P}<0.01)$ were observed among conventional and organically grown Green chilli for $\mathrm{Mg}, \mathrm{K}$ and vitamin $\mathrm{C}$, minerals such as $\mathrm{Fe}, \mathrm{Mg}$ and $\mathrm{Mn}$ for French bean and $\mathrm{Mg}$, Mn vitamin $\mathrm{C}$ for cauliflower (Table 4 and 7). $\mathrm{Ca}, \mathrm{Mg}, \mathrm{K}, \mathrm{Cu}$ content of sprouts is significantly different from each other. The $\mathrm{Fe}$ and $\mathrm{Zn}$ content of the Bengal gram and green gram and Bengal gram and horse gram were on par but there was significant difference between sodium content of green gram and horse gram (Table 3 and 4). 
Table 3. Standard values of mineral content $(\mathrm{mg} / 100 \mathrm{~g})$ in vegetables

\begin{tabular}{|c|c|c|c|c|c|c|c|c|c|}
\hline $\begin{array}{l}\text { Sl. } \\
\text { No. }\end{array}$ & Sample & $\begin{array}{l}\text { Potassium } \\
(\mathrm{mg} / 100 \mathrm{~g})\end{array}$ & $\begin{array}{c}\text { Magnesium } \\
(\mathrm{mg} / 100 \mathrm{~g})\end{array}$ & $\begin{array}{c}\text { Zinc } \\
(\mathrm{mg} / 100 \mathrm{~g})\end{array}$ & $\begin{array}{c}\text { Manganese } \\
(\mathrm{mg} / 100 \mathrm{~g})\end{array}$ & $\begin{array}{c}\text { Iron } \\
(\mathrm{mg} / 100 \mathrm{~g})\end{array}$ & $\begin{array}{c}\text { Copper } \\
(\mathrm{mg} / 100 \mathrm{~g})\end{array}$ & $\begin{array}{l}\text { Calcium } \\
(\mathrm{mg} / 100 \mathrm{~g})\end{array}$ & $\begin{array}{c}\text { Sodium } \\
(\mathrm{mg} / 100 \mathrm{~g})\end{array}$ \\
\hline 1 & Amaranthus & $597 \pm 118$ & $146 \pm 25.9$ & $1.03 \pm 0.3$ & $1.43 \pm 0.44$ & $5.28 \pm 0.7$ & $0.17 \pm 0.08$ & $0.010 \pm 0.004$ & $17.55 \pm 2.4$ \\
\hline 3 & Fenugreek leaves & $226 \pm 63.0$ & $63.67 \pm 18.5$ & $0.54 \pm 0.06$ & $0.84 \pm 0.34$ & $5.69 \pm 1.2$ & $0.54 \pm 0.06$ & $274 \pm 27.8$ & $47.01 \pm 4.2$ \\
\hline 4 & Mint & $539 \pm 2.7$ & $110 \pm 30.9$ & $0.75 \pm 0.08$ & $1.06 \pm 0.57$ & $8.56 \pm 3.2$ & $0.37 \pm 0.18$ & $205 \pm 31.8$ & $16.87 \pm 5.4$ \\
\hline 5 & Palak & $206 \pm 5.9$ & $86.97 \pm 8.58$ & $0.46 \pm 0.09$ & $1.12 \pm 0.42$ & $2.95 \pm 0.6$ & $0.17 \pm 0.05$ & $82.29 \pm 6.51$ & $42.55 \pm 4.1$ \\
\hline 7 & Cucumber & $183 \pm 36.6$ & $20.38 \pm 4.95$ & $0.17 \pm 0.02$ & $0.08 \pm 0.03$ & $0.46 \pm 0.2$ & $0.04 \pm 0.01$ & $16.39 \pm 3.74$ & $6.33 \pm 0.2$ \\
\hline 8 & Tomato & $167 \pm 18.9$ & $11.86 \pm 2.87$ & $0.11 \pm 0.02$ & $0.09 \pm 0.02$ & $0.22 \pm 0.0$ & $0.04 \pm 0.01$ & $8.90 \pm 1.04$ & $11.86 \pm 2.8$ \\
\hline 9 & Green chilli & $341 \pm 64.6$ & $29.51 \pm 7.13$ & $0.27 \pm 0.09$ & $0.28 \pm 0.10$ & $1.20 \pm 0.3$ & $0.15 \pm 0.06$ & $18.45 \pm 4.86$ & $2.50 \pm 0.08$ \\
\hline 10 & French bean & 317.00 & 34.98 & 0.37 & 0.27 & 0.98 & 0.07 & 49.90 & 9.18 \\
\hline 14 & Green gram & 843.00 & 127.00 & 4.60 & 2.47 & 4.40 & 0.39 & 124.00 & 28. .00 \\
\hline 15 & Horse gram & 762.00 & 157.00 & 2.80 & 1.57 & 6.77 & 1.81 & 287.00 & 11.78 \\
\hline 17 & Strawberry & $140 \pm 5.7$ & $15.53 \pm 1.3$ & $0.14 \pm 0.02$ & $043 \pm 0.02$ & $0.36 \pm 0.03$ & $0.07 \pm 0.01$ & $86.12 \pm 6.93$ & $7.37 \pm 0.14$ \\
\hline
\end{tabular}

Longvah, T., Ananthan, R., Bhaskarachary, K., \&Venkaiah, K. (2017). Indian food composition tables, National Institute of Nutrition, Indian Council of Medical Research, Department of Health Research, Ministry of Health and Family Welfare, Government of India 
Table 4. Mineral content (mg/100g) of conventional and organically grown vegetables in Mysore

\begin{tabular}{|c|c|c|c|c|c|c|c|c|c|c|c|}
\hline Sl No. & Sample & Method & Calcium & Iron & Magnesium & Sodium & Potassium & Copper & Manganese & Zinc & Vitamin C \\
\hline \multicolumn{12}{|c|}{ Green leafy vegetables } \\
\hline 1 & & Organic & $388.204 .2^{* * *}$ & $3.53 \pm 0.1_{\mathrm{b}}{ }^{* *}$ & $121.10 \pm 0.0_{\mathrm{d}}^{* *}$ & $16.70 \pm 0.2_{\mathrm{a}}$ & $341.90 \pm 0.2_{\mathrm{b}}{ }^{* *}$ & $0.10 \pm 0.0_{\mathrm{b}}^{* *}$ & $0.30 \pm 0.0^{* *}$ & $0.17 \pm 0.0_{\mathrm{d}}^{* *}$ & $74.42 \pm 0.3_{\mathrm{d}}$ \\
\hline \multirow[t]{2}{*}{3} & Fenugreek Leaves & Conventional & $284.39 \pm 0.2_{\mathrm{d}}{ }^{* *}$ & $5.61 \pm 0.0_{\mathrm{b}}{ }^{* *}$ & $480.84 \pm 0.0^{* *}$ & $49.12 \pm 0.2_{\mathrm{c}}$ & $258.61 \pm 0.0_{\mathrm{a}}^{* *}$ & $0.18 \pm 0.0_{\mathrm{ab}}$ & $0.81 \pm 0.0^{* *}$ & $0.54 \pm 0.0_{\mathrm{b}}^{*}$ & $56.43 \pm 0.1_{\mathrm{c}}{ }^{*}$ \\
\hline & & Organic & $292.00 \pm 0.0_{\mathrm{d}}^{* *}$ & $3.90 \pm 0.0_{\mathrm{b}}{ }^{* * *}$ & $54.20 \pm 0.0^{* *}$ & $45.20 \pm 0.0_{\mathrm{c}}$ & $235.20 \pm 0.0_{\mathrm{a}}^{* *}$ & $0.10 \pm 0.0_{\mathrm{ab}}$ & $0.20 \pm 0.0^{* *}$ & $0.34 \pm 0.0_{\mathrm{b}}{ }^{*}$ & $61.79 \pm 0.3_{\mathrm{c}}^{*}$ \\
\hline 4 & Mint & Conventional & $211.70 \pm 5.9{ }^{*}{ }^{*}$ & $8.54 \pm 1.0_{\mathrm{c}}^{*}$ & $147.23 \pm 6.0_{\mathrm{c}}{ }^{* *}$ & $12.75 \pm 1.3_{\mathrm{a}}$ & $529.15 \pm 4.3_{\mathrm{d}}$ & $0.50 \pm 0.0_{\mathrm{c}}{ }^{* *}$ & $1.12 \pm 0.1^{* *}$ & $0.00 \pm 0.0_{\mathrm{a}}^{* *}$ & $15.77 \pm 0.2_{\mathrm{a}}^{*}$ \\
\hline 5 & & Organic & $74.30 \pm 0.0_{\mathrm{a}}$ & $1.13 \pm 0.0_{\mathrm{a}}$ & $65.10 \pm 0.0_{\mathrm{b}}$ & $42.10 \pm 0.0_{\mathrm{b}}$ & $606.00 \pm 0.0_{\mathrm{e}}$ & $0.10 \pm 0.0_{b}$ & $0.50 \pm 0.0$ & $0.30 \pm 0.0_{b}$ & $31.56 \pm 0.4_{b}$ \\
\hline \multicolumn{12}{|c|}{ Salad vegeatbles } \\
\hline 6 & Cabbage & Conventional & $53.62 \pm 0.2_{\mathrm{c}}^{*}$ & $0.33 \pm 0.0_{\mathrm{b}}{ }^{*}$ & $19.88 \pm 0.10 .1_{\mathrm{b}}{ }^{*}$ & $14.21 \pm 0.0_{\mathrm{c}}$ & $274.54 \pm 0.0_{\mathrm{c}}{ }^{* *}$ & $0.03 \pm 0.0_{\mathrm{a}}$ & $0.21 \pm 0.0_{\mathrm{c}}$ & $0.20 \pm 0.0_{\mathrm{b}}{ }^{*}$ & $34.50 \pm 0.1_{\mathrm{b}}$ \\
\hline 7 & Cucumber & Organic & $44.00 \pm 0.9_{\mathrm{c}}{ }^{*}$ & $0.80 \pm 0.0_{\mathrm{b}}{ }^{*}$ & $15.00 \pm 0.0_{\mathrm{b}}{ }^{*}$ & $13.60 \pm 0.0_{\mathrm{c}}^{* *}$ & $248.45 \pm 0.0_{\mathrm{c}}^{* *}$ & $0.02 \pm 0.0_{\mathrm{a}}^{*}$ & $0.20 \pm 0.0_{\mathrm{c}}{ }^{* *}$ & $0.30 \pm 0.0_{\mathrm{b}}{ }^{*}$ & $35.19 \pm 0.0_{\mathrm{b}}{ }^{* *}$ \\
\hline 7 & Cucumber & Conventional & $18.37 \pm 0.0_{\mathrm{b}}^{* * * * *} \mathrm{~b}$ & $0.48 \pm 0.0_{\mathrm{b}}$ & $22.42 \pm 0.0_{\mathrm{b}}{ }^{* *}$ & $5.35 \pm 0.0 \mathrm{a}^{* *}$ & $210.39 \pm 0.0_{\mathrm{a}}^{* *}$ & $0.00 \pm 0.0_{\mathrm{a}}^{*}$ & $0.00 \pm 0.0_{\mathrm{b}}^{* *}$ & $0.10 \pm 0.0_{\mathrm{a}}^{* *}$ & $5.40 \pm 0.2_{\mathrm{a}}^{* *}$ \\
\hline 8 & Tomato & Organic & $9.10 \pm 0.1_{\mathrm{b}}^{* *}$ & $0.60 \pm 0.0_{\mathrm{b}}{ }^{* *}$ & $14.70 \pm 0.1_{\mathrm{b}}^{* * *}$ & $10.20 \pm 0.1_{\mathrm{a}}^{* *}$ & $49.93 \pm 0.0_{\mathrm{a}}^{* *}$ & $0.09 \pm 0.0_{\mathrm{a}}^{*}$ & $0.10 \pm 0.0_{\mathrm{b}}^{* *}$ & $0.20 \pm 0.0_{\mathrm{a}}^{* *}$ & $7.15 \pm 0.2_{\mathrm{a}}^{* *}$ \\
\hline 11 & Brinjal & Organic & $49.29 \pm 0.2_{\mathrm{b}}$ & $0.62 \pm 0.0_{\mathrm{b}}{ }^{*}$ & $38.70 \pm 0.0{ }_{\mathrm{d}}{ }^{*}$ & $8.00 \pm 0.0_{\mathrm{c}}$ & $120.40 \pm 0.1_{\mathrm{a}}^{* *}$ & $0.10 \pm 0.0_{\mathrm{a}}$ & $0.10 \pm 0.0_{\mathrm{a}}{ }^{*}$ & $0.30 \pm 0.0_{\mathrm{a}}$ & $1.80 \pm 0.2_{\mathrm{a}}^{* *}$ \\
\hline 11 & Brinjal & Conventional & $17.55 \pm 0.0_{\mathrm{a}}$ & $0.34 \pm 0.0_{\mathrm{a}}$ & $23.90 \pm 0.0{ }_{\mathrm{a}}^{* *}$ & $3.56 \pm 0.0_{\mathrm{b}}$ & $287.53 \pm 0.0_{\mathrm{b}}{ }^{*}$ & $0.14 \pm 0.0_{\mathrm{b}}$ & $0.16 \pm 0.0 \mathrm{a}$ & $0.20 \pm 0.0_{\mathrm{a}}$ & $2.50 \pm 0.1_{\mathrm{c}}^{* *}$ \\
\hline 12 & Cauliflower & Organic & $16.96 \pm 0.0_{\mathrm{a}}^{* *}$ & $0.37 \pm 0.0_{\mathrm{a}}$ & $15.20 \pm 0.0_{\mathrm{a}}^{* * *}$ & $3.20 \pm 0.0_{\mathrm{b}}$ & $247.70 \pm 0.4_{b}^{* *}$ & $0.10 \pm 0.0_{\mathrm{b}}$ & $0.10 \pm 0.0_{\mathrm{a}}^{*}$ & $0.20 \pm 0.0_{\mathrm{a}}{ }^{* *}$ & $4.29 \pm 0.0_{\mathrm{c}}^{* *}$ \\
\hline 12 & Cauliflower & Conventional & $24.17 \pm 0.0_{\mathrm{b}}{ }^{* *}$ & $0.96 \pm 0.0_{\mathrm{b}}$ & $21.10 \pm 0.0_{\mathrm{b}}{ }^{*}$ & $29.71 \pm 0.0_{\mathrm{d}}$ & $357.27 \pm 0.0_{\mathrm{c}}{ }^{* *}$ & $0.05 \pm 0.0_{\mathrm{a}}$ & $0.23 \pm 0.0_{\mathrm{a}}^{*}$ & $0.30 \pm 0.0_{\mathrm{a}}^{* *}$ & $48.35 \pm 1.6_{\mathrm{b}}{ }^{* *}$ \\
\hline \multicolumn{12}{|c|}{ Conventionally grown sprouts } \\
\hline 13 & Bengal gram & Conventional & $200.83 \pm 1.4_{b}$ & $4.05 \pm 0.2 \mathrm{~b}$ & $116.40 \pm 1.0 \mathrm{a}$ & $34.34 \pm 1.6_{\mathrm{ab}}$ & $799.99 \pm 2.1_{b}$ & $1.16 \pm 0.0_{\mathrm{b}}$ & $1.20 \pm 0.0_{\mathrm{a}}$ & $5.55 \pm 0.2_{\mathrm{b}}$ & $7.5 \pm 0.1_{\mathrm{b}}$ \\
\hline 14 & Green gram & Conventional & $121.40 \pm 1.5_{\mathrm{a}}$ & $4.00 \pm 0.3_{\mathrm{a}}$ & $125.83 \pm 1.5_{\mathrm{b}}$ & $45.81 \pm 26.7_{\mathrm{b}}$ & $716.87 \pm 3.8 \mathrm{a}$ & $0.33 \pm 0.0_{\mathrm{a}}$ & $2.32 \pm 0.01_{b}$ & $2.89 \pm 0.0_{\mathrm{a}}$ & $14.5 \pm 0.7_{\mathrm{c}}$ \\
\hline
\end{tabular}

abc Subscript letters indicate significant differences among the mineral content between crops tested. Means that share the same subscript letter are not significantly different from one another; means with different subscript letters are significantly different $(\mathrm{P}<0.05)$.

** indicate highly significant differences $(\mathrm{P}<0.01)$ among conventional and organic vegetables for their mineral content.

$*$ indicate significant differences $(\mathrm{P}<0.05)$ among conventional and organic vegetables for their mineral content. 


\section{Estimation of vitamin $C$ in conventional and organically grown vegetables}

There were significant ( $p>0.05)$ difference in vitamin $C$ content between organic and conventionally grown vegetables. Highly significant differences were found between conventional and organically grown brinjal, cucumber and tomato. and significant difference was found between conventional and organically grown green chilli and cauliflower (Table 3 and 4). Worthington (2001) found out that organic crops contained significantly more vitamin $\mathrm{C}$, iron, magnesium, and phosphorus and significantly less nitrates than conventional crops. Masamba et al. (2008) carried out studies to determine and compare vitamin $\mathrm{C}$, calcium and potassium in organically and conventionally grown cabbage, carrots, Cos lettuce and Valencia oranges from New South Wales in Australia. No significant differences were observed in vitamin C content in conventionally and organically grown cabbage, carrots and lettuce while calcium and potassium showed significant differences in all organic samples of cabbage, carrots and lettuce.

Hunter et al. (2011) evaluated the micronutrient composition of organic and conventional plant foods with a systematic analysis. Organic plant foods (vegetables, legumes and fruit) were found to have a $5.7 \%$ higher content of vitamins and minerals than their conventionally grown counterparts. Irrespective of cultivar, soil type, harvest conditions, and chemical analysis, organic plant foods contained significantly higher amounts of minerals, including phosphorus, compared to conventional foods. Furthermore, it has been proposed that organically produced plants synthesize higher levels of ascorbic acid than conventionally-grown plants, in response to biological and ecological stresses, and the absence of protection conferred by synthetic pesticides. Our results were similar for ascorbic content; higher ascorbic contents were found in organically grown vegetable samples. Similar study was conducted by Brandt et al. (2011), organic plant material had higher levels of vitamins $C$ than conventional vegetables and fruits. Thippeswamy (2013) reviewed the fact that food produced using organic methods taste better and nutritious.

\section{Prevalence of heavy metals ( $\mathrm{Pb}$ and $\mathrm{Cd}$ ) in conventional and organically grown vegetables}

Heavy metal analysis found that the lead and cadmium were present only in conventionally grown vegetable samples. The safe limit for lead and cadmium is 0.3 ppm and $0.2 \mathrm{ppm}$ respectively as per FAO/WHO (2008). In conventionally grown vegetable sample maximum level of heavy metal was found in fenugreek leaves (5.0 $\mathrm{ppm})$, cauliflower $(4.0 \mathrm{ppm})$, amaranthus $(2.0 \mathrm{ppm})$ and $(1.0 \mathrm{ppm})$ in coriander, palak and brinjal. In other conventionally grown vegetables there was no presence of lead. Among sprouts, horse gram $(6.0 \mathrm{ppm})$ showed maximum level of lead followed by Bengal gram $(5.0 \mathrm{ppm})$. In protected cultivation crops there was no trace of heavy metals found. Cadmium level in conventionally grown vegetables was found maximum in brinjal and horse gram (1.0 ppm) only (Fig. 2). 
Sharam et al. (2006) conducted a study on heavy metal contamination in vegetables grown in Varanasi region and reported that GLV (amaranthus, palak) and salad vegetable (cabbage) had heavy metal $(\mu \mathrm{g} / \mathrm{g}$ dry weight) ranging between 1.55 to 6.90 for $\mathrm{Cd}$ and 9.00 to 28.00 for $\mathrm{Pb}$. Roba et al., (2016) investigated the concentrations of $\mathrm{Zn}, \mathrm{Cu}, \mathrm{Pb}$, and $\mathrm{Cd}$ in several vegetables cultivated in Baia Mare mining area (Romania) and concentration order of heavy metals was $\mathrm{Zn}>\mathrm{Cu}>\mathrm{Pb}>\mathrm{Cd}$. Sharma et al., (2009) reported the heavy metal concentration in vegetables from tropical urban area of India, the mean concentration of $\mathrm{Cu}$ in cauliflower, and of $\mathrm{Zn}$ and $\mathrm{Cd}$ in palak and cauliflower had exceeded the FSSAI standards (FSSAI, 2016). Zn at the production sites also exceeded the PFA standard in cauliflower. Heavy metals accumulation in vegetables tested were higher at market sites than crop production sites. The heavy metal concentration in palak and cauliflower for Cd varied from 0.4 to 1.5 , and 0.6 to $2.1 \mu \mathrm{g} / \mathrm{g}$, and of $\mathrm{Pb}$ varied from 0.7 to 1.4 and 0.2 to $1.8 \mu \mathrm{g} / \mathrm{g}$, respectively. In a study conducted by Ramesh and Murthy (2012), randomly collected waste water, soil and green leafy vegetable samples from Bangalore and analysed for the heavy metals namely $\mathrm{Cu}, \mathrm{Zn}, \mathrm{Pb}, \mathrm{Cr}, \mathrm{Cd}$ and $\mathrm{Mn}$. Results showed that, $\mathrm{Pb}$ concentration was exceedingly high in palak (28.43 ppm to $149.50 \mathrm{ppm}$ ) and coriander (54.69 ppm to $75.50 \mathrm{ppm})$ in all sampling stations, $\mathrm{Cr}$ content in palak $(70.79 \mathrm{ppm})$ and coriander (127.27 ppm) was alarmingly exceeding the allowable limit.

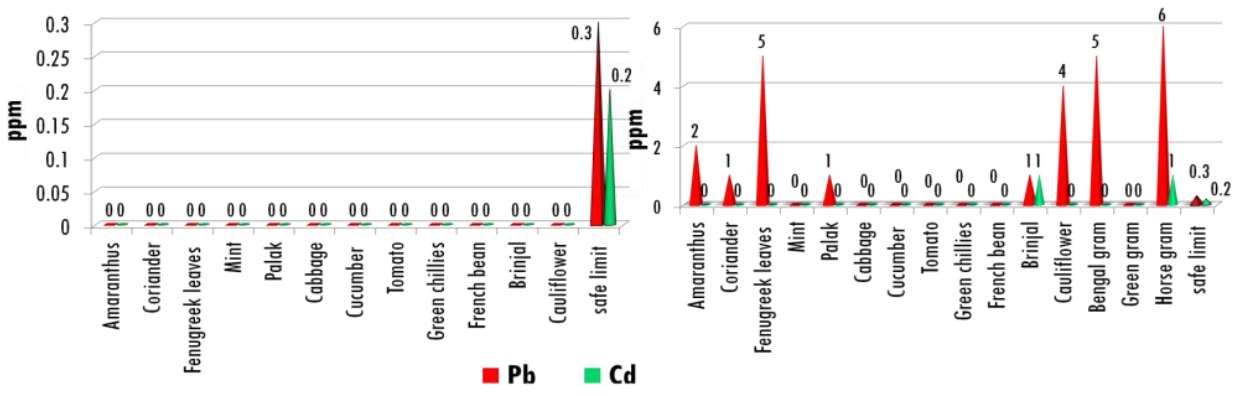

Figure 2. Heavy metal analysis of organically and conventionally grown vegetables

Principal component analysis of organic, conventional and protected cultivated vegetables and their microbial safety and nutritive value

The projection of variables and cases on factor plane explains that all the factors showed a positive effect on variables tested whereas manganese and copper were found to show a negative effect (Fig. 3a and 3b). In PC1, one conventional sample (C16) and one organic sample (O18) and conventional sprouts samples had large positive and negative scores for PC2, respectively. Conventional (16) and organic (18) had higher amounts of $\mathrm{Mg}, \mathrm{K}$, $\mathrm{Ca}, \mathrm{Pb}$ and Ash while conventional sprouts samples had $\mathrm{Mg}, \mathrm{K}, \mathrm{Ca}, \mathrm{Pb}$ and Ash than the other samples. In PC2, the protected cultivation samples and conventional samples (tomato, cucumber, brinjal and French bean) had large positive and negative scores for PC2, respectively. The protected cultivated samples had higher amounts of $\mathrm{Fe}, \mathrm{Na}$ and 
Vit $\mathrm{C}$ and lesser $\mathrm{YM}$ counts while conventional samples of tomato, cucumber, brinjal and French bean had lower amounts of $\mathrm{Fe}, \mathrm{Na}$ and Vit $\mathrm{C}$ and higher YM counts. The scores for the samples showed no tendency towards separation of organic and conventional samples (Fig. 3b).

Dendrogram for HCA results did not separate organic and conventional samples into distinct groups and graphical representations of HCA are called dendrograms (Chun et al., 2010) (Fig. 4). The linkage distances were between 440 and 500, confirmed the result obtained in PCA. This shows that the two groups in the two-dimensional projection are even more separate in real space as the dendrograms are based on real distances between samples while PCA are only projections. These techniques have been employed in characterization of foods such as broccoli (Santos et al., 2013) cabbage (Anunciaçao et al., 2013), wheat flour (Lima et al., 2010), kale (Fadigas et al., 2010) and beans (Santos et al., 2009).

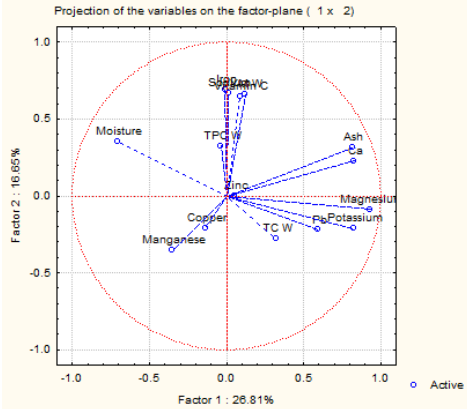

(a)

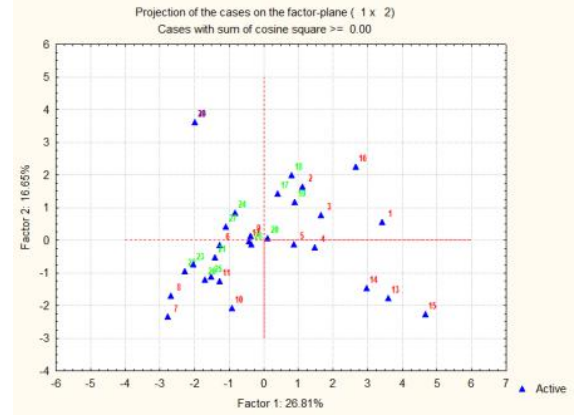

(b)

Red color-conventional samples; Green color- organic samples and; Purple color- protected cultivation samples

Figure 3. (a) Projection of variables on the factor plane (b) Score plot for factor 1 and factor 2 (projection of cases on the factor plane)

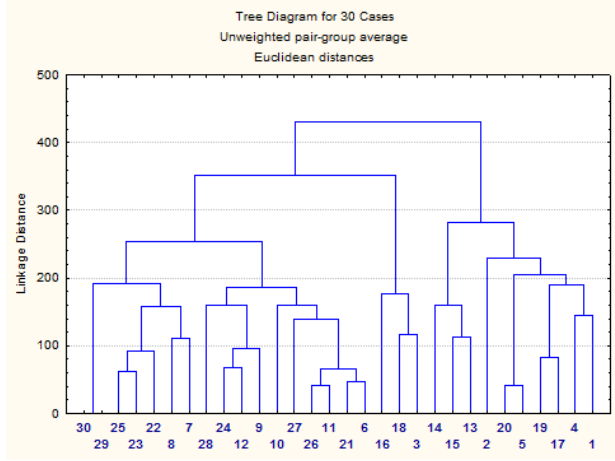

Figure 4. Dendrogram for conventional and organic sample showing wards method with Euclidean distance 


\section{CONCLUSIONS}

Our study indicated that organically cultivated GLVs such as amaranthus, coriander, fenugreek leaves and mint, tomato and cauliflower were found superior than their conventionally grown counterparts in microbial quality. E. coli contamination and internalization of the pathogen was found in all conventional, organic and protected cultivation samples except French bean which indicate the necessity of thorough surface decontamination through washing, ozonisation etc. of fresh produce prior to consumption and processing applications. Consumption of these conventionally grown produce as raw salad may lead to food borne illness while all organically grown vegetables sampled tested negative for Shigella sp. and are safe to be consumed raw. Lead $(0.3 \mathrm{ppm})$ contamination exceeded the safe limit in conventionally cultivated fenugreek leaves, cauliflower, amaranthus coriander, palak and brinjal and sprouts such as horse gram and Bengal gram while brinjal and horse gram exceeded the safe limit for cadmium $(0.2 \mathrm{ppm})$ making these vegetables unsafe for consumption. Organically grown and protected cultivation vegetables tested negative for heavy metals and higher nutrient contents and were safe for consumption.

\section{ACKNOWLEDGEMENT}

The authors are thankful to Dr GK Sharma, DFRL, Mysore for editing the manuscript and Dr MM Parida, DFRL, Mysore for providing microbiology laboratory facility. Authors are also thankful to Dr Pal Murugan M, Scientist, DFRL for statistical analysis of the data.

\section{REFERENCES}

AOAC. (2000). Association of Official Analytical Chemists. Official methods of Analysis (Vol. II 17th edition) of AOAC International. Washington, DC, USA. Official methods 925.09, 923.03,979.09, 962.09, 4.5.01 and 923.05.

Begum, A. and Harikrishna, S. (2010). Pathogens and Heavy Metals Concentration in Green Leafy Vegetables. Journal of Chemistry, 7(S1):S552-S558

Berger, C.N., Sodha, S.V., Shaw, R.K., Griffin, P.M., Pink, D., Hand, P. and Frankel, G. (2010). Fresh fruit and vegetables as vehicles for the transmission of human pathogens. Environmental microbiology, 12(9):2385-2397.

Brandt, K. and Molgaard, J.P. (2001). Organic agriculture: does it enhance or reduce the nutritional value of plant foods? Journal of the Science of food and agriculture, 81(9): 924-931.

Chun, M.H., Kim, E.K., Lee, K.R., Jung, J.H. and Hong, J. (2010). Quality control of Schizonepetatenuifolia Briq by solid-phase microextraction gas chromatography/mass spectrometry and principal component analysis. Microchemical Journal, 95(1):25-31.

Crinnion, W.J. (2010). Organic foods contain higher levels of certain nutrients, lower levels of pesticides, and may provide health benefits for the consumer. Alternative Medicine Review, 15(1):4-12. 
Eni, A.O., Oluwawemitan, I.A., and Solomon, O.U. (2010). Microbial quality of fruits and vegetables sold in Sango Ota, Nigeria. African Journal of Food Science, 4(5):291-296.

Food Safety and Standards. (2016). Related to limit of Heavy Metals in food. [Amendment in the Food Safety and Standards (Contaminants, Toxins and Residues) Regulation, 2011: Regulation 2.1, in sub-regulation 2.1.1, in clause 2].

Hunter, D., Foster, M., McArthur, J.O., Ojha, R., Petocz, P. and Samman, S. (2011). Evaluation of the micronutrient composition of plant composition of plant foods produced by organic and conventional agricultural methods. Critical Reviews in Food Science and Nutrition, 51(6):571-582

Maffei, D.F., Batalha, E.Y., Landgraf, M., Schaffner, D.W. and Franco, B.D. (2016). Microbiology of organic and conventionally grown fresh produce. Brazilian journal of microbiology, 47:99-105.

Masamba, K.G. and Nguyen, M. (2008). Determination and comparison of vitamin C, calcium and potassium in four selected conventionally and organically grown fruits and vegetables. African Journal of Biotechnology, 7(16):2915-2919.

Merlini, V.V., Pena, F.D.L., da Cunha, D.T., de Oliveira, J.M., Rostagno, M.A. and Antunes, A.E.C. (2018). Microbiological Quality of Organic and Conventional Leafy Vegetables. Journal of Food Quality. doi.org/10.1155/2018/4908316.

Ramesh, H.L. and Murthy, Y.V. N. (2012). Assessment of heavy metal contamination in green leafy vegetables grown in Bangalore urban district of Karnataka. Advances in Life Science and Technology, 6: 2012.

Rembiałkowska, E. (2007). Quality of plant products from organic agriculture. Journal of the Science of Food and Agriculture, 87(15):2757-276.

Ren, G., Hu, D., Cheng, E.W.C., Vargas-Reus, M.A., Reip, P. and Allaker, R.P. (2009). Characterisation of copper oxide nanoparticles for antimicrobial applications. International Journal of Antimicrobial Agents, 33:587-90.

Roba, C., Roşu, C., Piştea, I., Ozunu, A. and Baciu, C. (2016). Heavy metal content in vegetables and fruits cultivated in Baia Mare mining area (Romania) and health risk assessment. Environmental Science and Pollution Research, 23(7):6062-6073.

Said, D.S. (2012) Detection of parasites in commonly consumed raw vegetables. Alexandria Journal of Medicine, 48(4): 345-352.

Santos, I.F., dos Santos, A.M., Barbosa, U.A., Lima, J.S., dos Santos, D.C., and Matos, G.D. (2013). Multivariate analysis of the mineral content of raw and cooked okra (Abelmoschus esculentus). Microchemical Journal, 110:439-443.

Santos, W.P.C., Castro, J.T., Bezerra, M.A., Fernandes, A.P., Ferreira, S.L.C., and Korn, M.G.A. (2009). Application of multivariate optimization in the development of an ultrasound-assisted extraction procedure for multielemental determination in bean seeds samples using ICP OES. Microchemical Journal, 91(2):153-158

Shahid, M., Camille, D., Sana, K., Eva, S., Tiantian, X. and Niazi, N.K. (2016) Foliar heavy metal uptake, toxicity and detoxification in plants: A comparison of foliar and root metal uptake. Journal of Hazardous Materials, 325:36-58. 
Sharma, R.K., Agrawal, M. and Marshall, F. (2006) Heavy metal contamination in vegetables grown in wastewater irrigated areas of Varanasi, India. Bulletin of Environmental Contamination and Toxicology, 77(2):312-318.

Sharma, R.K., Agrawal, M., and Marshall, F.M. (2009). Heavy metals in vegetables collected from production and market sites of a tropical urban area of India. Food and chemical toxicology, 47(3):583-591.

Snedecor, G.W. and Cochran, W.B. (1994). Statistical Methods. 8th ed. Lowa State University Press, Ames, lowa, USA.

Somasundram, C., Razali, Z. and Santhirasegaram, V. (2016) A Review on Organic Food Production in Malaysia. Horticulture, 2(3):12

Sospedra, I., Manes, J. and Soriano, J.M. (2012) Report of toxic shock syndrome toxin 1 (TSST-1) from Staphylococcus aureus isolated in food handlers and surfaces from foodservice establishments. Ecotoxicology and Environmental Safety, 80:288-290.

Thippeswamy, E. (2013). (2013). Heavy Metal Contamination in Vegetables Grown in Wastewater Irrigated Areas of Varanasi, India Comparative Analysis of Organic and Inorganic Food. IOSR Journal of Agriculture and Veterinary Science. 4(6), Pp 53-57

USFDA. (1999). Microbiological safety evaluations and recommendations on sprouted seed. Maryland, USA: U.S. Food and Drug Administration.

Viswanathan, P. and Randhir, K. (2001). Prevalence and growth of pathogens on salad vegetables, fruits and sprouts. International Journal of Hygene and Environmental Health. 203:205-213

Wadamori, Y., Ravi, G. and Malik, A.H. (2016). Outbreaks and factors influencing microbiological contamination of fresh produce. Journal of the Science of Food and Agriculture. 97(5):1396-1403.

Weldezgina, D. and Muleta, D. (2016). Bacteriological Contaminants of Some Fresh Vegetables Irrigated with Awetu River in Jimma Town, Southwestern Ethiopia. Pp. 1- 11.

WHO/FAO. (2008). Joint FAO/WHO Food Standard Programme Codex Alimentarius Commission 13th Session. Report of the Thirty Eight Session of the Codex Committee on Food Hygiene. Houston, United States of America, ALINORM 07/30/13.

Worthington, V. (2001). Nutritional quality of organic versus conventional fruits, vegetables, and grains. The Journal of Alternative Complementary Medicine, 7(2):161-173. 